\title{
Geomorfológiai tanulmányúton a Małopolskie régióban
}

\section{(Jagiellonian University, Krakkó, Lengyelország, 2014. április 7-12.)}

\author{
Kalmár Péter ${ }^{1}$ - Józsa Edina ${ }^{2}$ \\ ${ }^{1}$ MSc hallgató, PTE TTK Földrajzi Intézet, E-mail: kpeter@gamma.ttk.pte.hu \\ ${ }^{2}$ MSc hallgató, PTE TTK Földrajzi Intézet, E-mail: edina.j0zs4@gmail.com
}

\section{DOI: 10.17799/2014.1.35}

A Campus Hungary ösztöndíj keretében szervezett tanulmányút helyszínének kiválasztásában két kiemelkedő szempont játszott szerepet. A geomorfológia szakirányos mesterhallgatók számára a hazaitól markánsan eltérő formakincs és tájkép megismerését szolgáló terepbejárásokra lehetőséget adó mintaterület, illetve egy olyan egyetemi kutatóhely felkeresése, ahol a geomorfológiai kutatásokban alkalmazható eszközök bemutatására és kipróbálására is alkalom nyílhat. A pályázatban a küldő és fogadó intézmény között fennálló hosszú távú szakmai kapcsolat is mérvadó volt a döntés során. A Jagelló Tudományegyetem és a PTE TTK több mint 10 éve bilaterális szerződést kötött oktatócserére, 5 éve közös CEEPUS hálózat tagjai, valamint 2 éve ERASMUS/ERASMUS+ ösztöndíj kapcsolatot is kialakítottak. Emellett a PAN IGiPZ (Polish Academy of Sciences, Institute of Geography and Spatial Organization) munkatársaival is régóta tartó szakmai kapcsolatot ápol a Földrajzi Intézet az érintett szakterületen. A különböző csereprogramok révén a két egyetem földrajzi intézetének oktatói, $\mathrm{PhD}, \mathrm{MSc}$ és BSc hallgatói már több alkalommal jutottak el partnerintézményükbe és vettek részt közös szakmai tevékenységeken, terepi munkákon. A szakmai kapcsolatok révén már szakdolgozat is született. A geomorfológia diszciplínán belül Krakkó kiemelkedő, európai szintü kutatóhely, komoly terepi és labor eszközparkkal, kutatóállomásokkal. Több olyan módszer tanulmányozására, kipróbálására van lehetöség, amely Pécsen elérhetetlen.

A krakkói felsőoktatás, hasonlóan a pécsi egyetemhez, nagy múltra tekint vissza. III. Kázmér több éves igyekezete eredményeképpen, 1364-ben a pápa engedélyével egyetemet alapíthatott Közép-Európa e kiemelkedő városában. A történelmi belvárosban elszórtan elhelyezkedő egyetemi épületek napjainkban nem tudtak lépést tartani a megnövekedő hallgatói létszámmal, ezért 1999 óta folyamatosan egy modern kampusz kiépítésén dolgoznak. Ez az új épülettömb a Zakrzówek és Pychowice városrészek között, a központtól közel 4 km-re terül el (1. ábra).

A tanulmányút első napjaiban lehetőségünk volt betekintést nyerni a Földrajzi Intézet újonnan kialakított és modern müszerekkel felszerelt kutatólaborjaiba, ahol többek között szemcseeloszlás mérö, kőzetmikroszkóp, beütő talajmintavevő, dendro-geomorfológiai vizsgálatokra alkalmas müszerek gyakorlati alkalmazásával ismerkedhettünk meg (2. ábra).

A tanulmányút jelentős részét a terepbejárások töltötték ki. A vezetésünkre felkért doktorandusz kapcsolattartónk (Mateusz Sobucki) elsőként Krakkó környékének geomorfológiai viszonyait mutatta be - a térséget ábrázoló

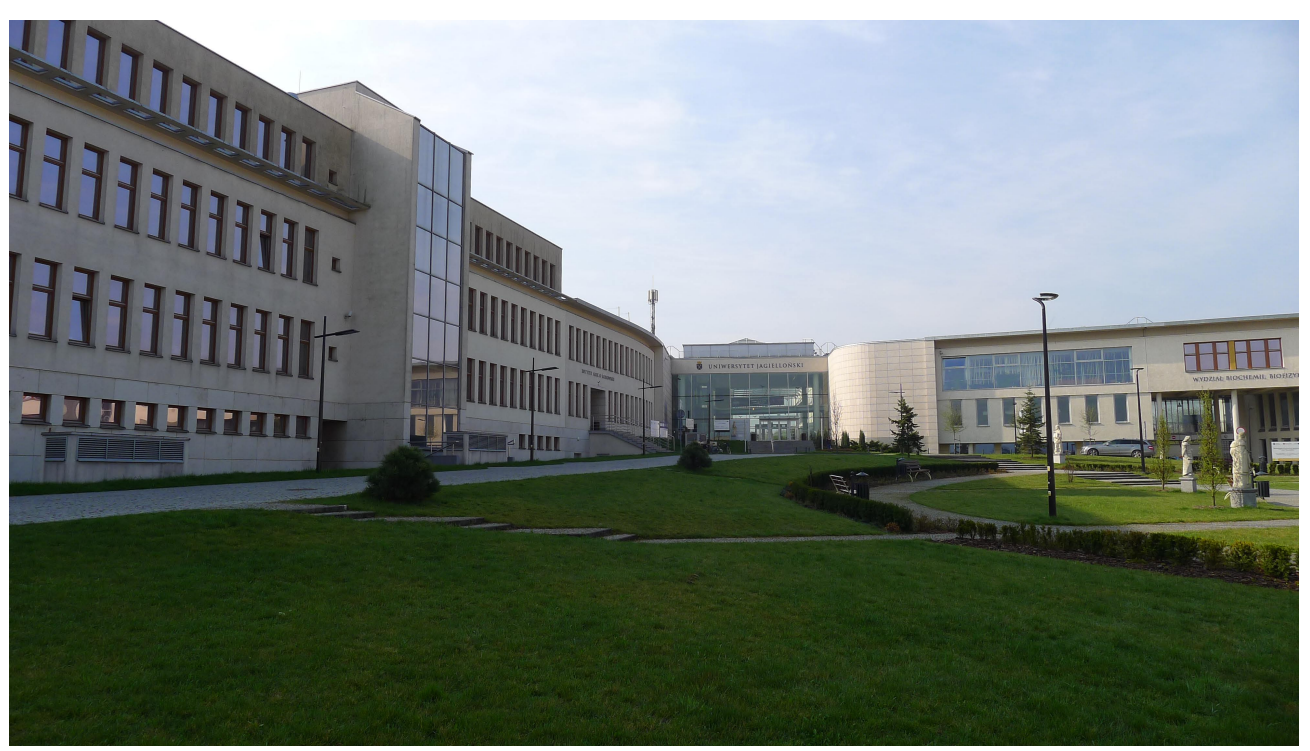

1. ábra: A Biológia és Földtudományi Kar új épülete. (Fotó: Kalmár P.) 


\section{TFK}

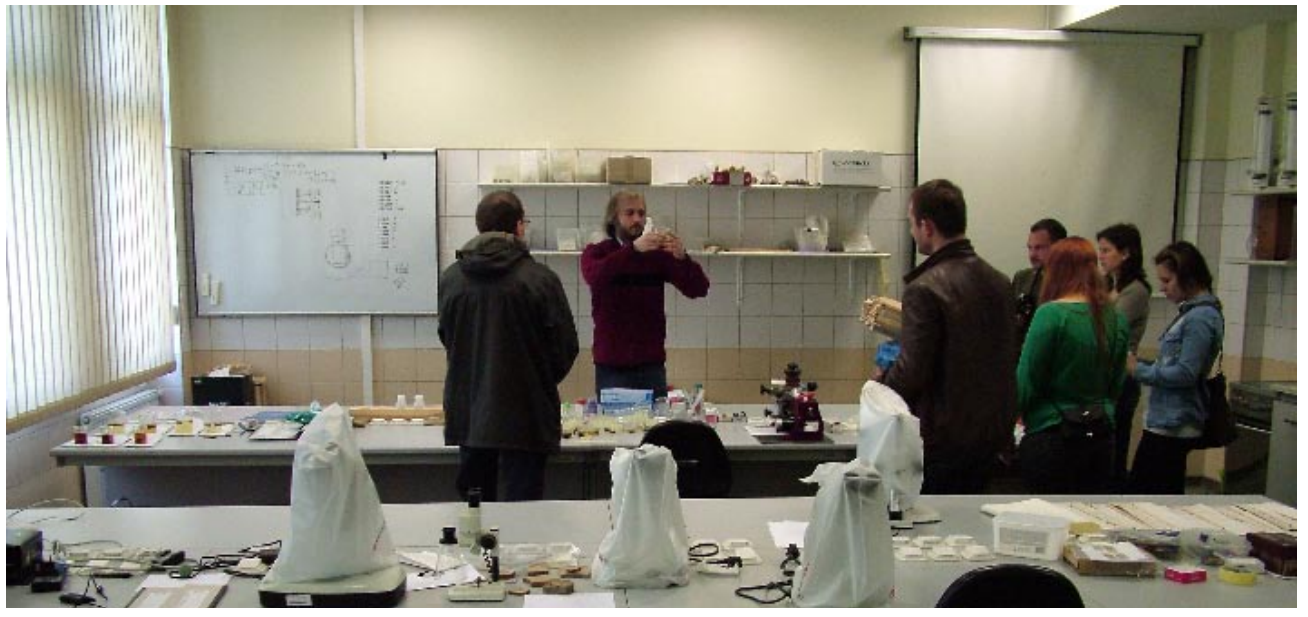

2. ábra: Bemutató a dendro-geomorfológiai laborban. (Fotó: Varga T.) lepítéséröl, müködéséröl is (4. ábra).

A csoport minden tagja profitált szakmailag abból, hogy a csoportos tanulmányút munkanyelve angol volt, így a hallgatók használták nyelvtudásukat, valamint a kutatások bemutatása, terepbejárások során szóba került földtani, geomorfológiai szakkifejezéseket is megismerték. Mindemellett a hallgatók nagy része saját kutatásaihoz tudja alkalmazni a megszerzett ismereteket.

geomorfológia térképet összevetve a város nevezetességei közé tartozó egyik ún. kopiecről, kisebb mesterséges dombról elénk táruló valósággal. Beszámolt a város terjeszkedését befolyásoló környezeti tényezőkröl, különös tekintettel a földtani és geomorfológiai sajátosságokra.

A Krakkótól északra elhelyezkedő Ojców Nemzeti Parkban tettünk tanulmányi kirándulást. A terepbejárás során megfigyeltük az alacsony mészkőfennsík formakincsét (kiemelt látványosság „Herkules buzogánya”, amely egy kipreparálódott mészkőoszlop), az ott zajló karsztos folyamatokat. Vezetőink elmagyarázták a terület glaciális felszínfejlődésének sajátosságait, a barlangok és a területet tagoló völgyek fejlődéstörténetét. Mindezt összevetettük a hazánkban már publikált travertin- és barlangi-sztratigráfiával. Emellett a nemzeti park kultúrtörténeti emlékeit is megtekintettük: Vízi Kápolna, Pieskowa Skała kastély, várrom (3. ábra).

Egy egész napos terepmunka során ellátogattunk a Tátra Nemzeti Parkban található Chocholowska-völgybe, ahol megfigyeltük egyrészt a recens geomorfológiai folyamatokat (lavinák kialakulása, forrásfeltörések, medermorfológiai folyamatok), illetve a 2013/14 telén pusztító szélvihar következményeit. A területet vizsgáló doktorandusz (Eliza Płaczkowska) részletesen beszámolt a térség földtani és geomorfológiai viszonyairól. Kutatási témájának bemutatásaként tájékoztatást kaptunk a völgyhöz kapcsolódó részvízgyüjtők eróziós folyamatairól, a kutatása során alkalmazott módszerekről (vízszint-mérés, klimatikus mérések, fluviális eróziós mérések megfestett kavicsok monitoringjával), valamint a terepbejárás során a kihelyezett mérőmüszerek te-

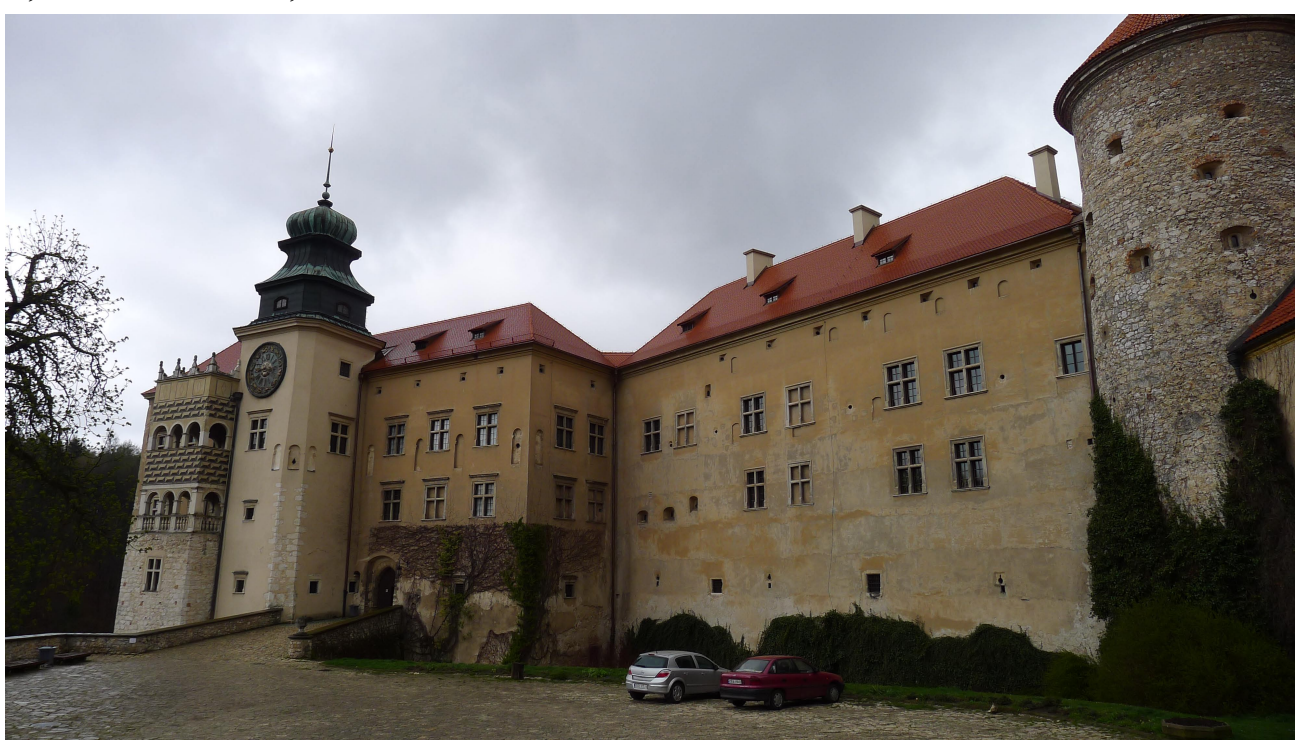

3. ábra: Pieskowa Skała kastély. (Fotó: Kalmár P.) 


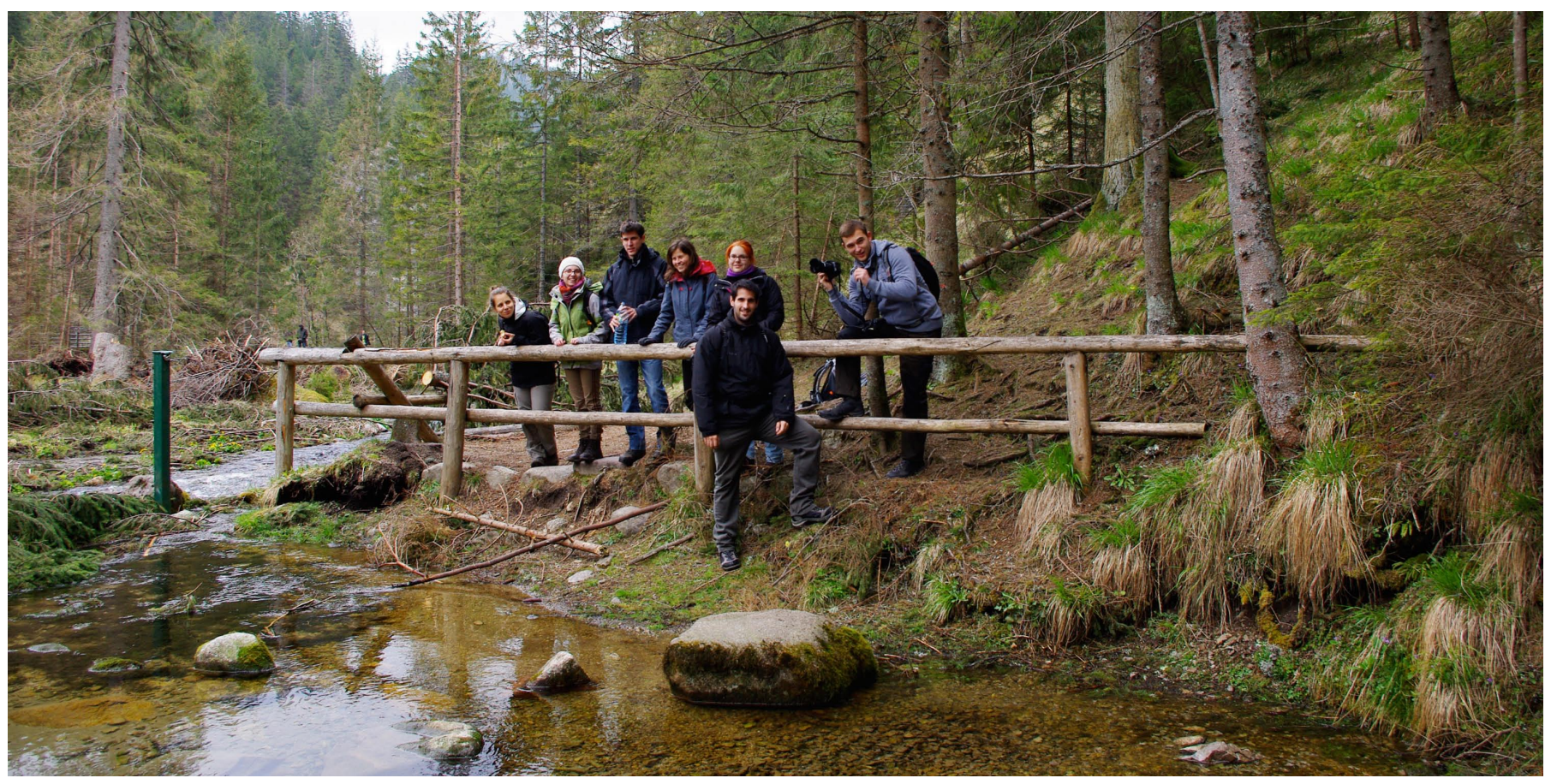

4. ábra: A PTE TTK FI ifjú geomorfológusai. (Fotó: Kovács I. P.) 
